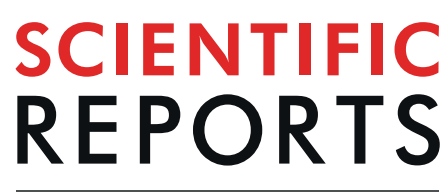

natureresearch

Check for updates

\title{
In-vitro bioaccessibility and bioavailability of heavy metals in mineral clay complex used in natural health products
}

\begin{abstract}
Xiumin Chen $\mathbb{1}^{1,2}$, Anika Singh ${ }^{1}$ \& David D. Kitts ${ }^{1 凶}$
Commercial mineral clays that claim to have healing properties are also known to contain trace amounts of heavy metals, albeit the risk of consuming many of them is not entirely known. The primary objective of this study was to evaluate the in vitro bioaccessibility and bioavailability of Arsenic (As), Cadmium ( $\mathrm{Cd}$ ) and Lead $(\mathrm{Pb})$ in mineral clay samples collected from the Sierra Mountains (USA) using the Unified Bioaccessibility Research Group of Europe (UBM) method and the Caco-2 permeability assay, respectively. After UMB-gastric (UBM-G) digestion, As and Pb bioaccessibility were lower compared to $\mathrm{Cd}$ and decreased further in the UMB-gastrointestinal (UBM-GI) assay. Bioavailability estimates using the Caco-2 cell showed very low to non-detectable permeability for all 3 heavy metals. Thus, while initial heavy metal ranged from 3.8-17 ppm, 0.024-0.061ppm, and 5.8-20 ppm for As, Cd, and $\mathrm{Pb}$, respectively, the bioavailability for these metals was reduced to very low levels that followed: non-detectable values of $\mathrm{As},<0.007 \mathrm{ppm}$ of $\mathrm{Cd}$, and $<0.1 \mathrm{ppm}$ of $\mathrm{Pb}$. Using UBM-digestion to mimic bioaccessibility, followed by Caco- 2 cell bioavailability enabled us to conclude that in vitro assessment of heavy metal exposure associated with mineral clay-based natural health products does not pose a potential hazard to consumers.
\end{abstract}

Commercially available mineral clay products are widely used by consumers to relieve joint pain and muscle soreness, as well as a treatment for other chronic disease $\mathrm{e}^{1,2}$. Mineral clay acidic extracts, in particular, are known to suppress the production of nitric oxide which is an important mediator for inflammatory reactions that cause the thinning of cartilage tissue ${ }^{3}$. Several clinical studies also report that naturally found mineral clays have the potential to improve overall joint health and function well in mild to moderate cases of osteoarthritis (OA) in patients $^{3-6}$. It is to be noted that, OA is a major cause of disability in elderly populations around the globe ${ }^{7}$. In Canada, in particular; approximately $0.9 \%$ of Canadian adults (e.g. more than 272,000 people) suffer from OA, which translates to a substantial cumulative economic burden that has an estimated cost of $\$ 195.2$ billion $^{8}$. The hydrothermal mineral complex obtained from the Sierra Mountains in the United States is one such source of therapeutic clay. These clay products are rich in essential minerals, but also include potentially harmful heavy metals such as Arsenic (As), Cadmium $(\mathrm{Cd})$ and Lead $(\mathrm{Pb})$ at very low concentrations. Data from initial trials have also shown that depending on the ingestion dose, the levels of As and $\mathrm{Pb}$ present in these mineral clays could exceed current Health Canada's tolerance limits, established for heavy metals present in natural health products?. Hence, despite having an important health benefit for OA patients, the total toxic heavy metal content in such mineral clay products that is bioaccessible and bioavailable needs to be evaluated to ensure the safety of these products.

In this study, we use the term heavy metal "bioaccessibility" to describe the fraction of heavy metals that is released from a mineral matrix into the gastrointestinal tract upon digestion; while the term "bioavailability" refers to the proportion of heavy metals that are absorbed from the intestine to enter the systemic circulation and thus available to induce a potentially toxic effect ${ }^{10,11}$. For our purposes, bioaccessibility was determined by the maximum soluble concentration of metals that were released from the sample clay mineral matrix using a synthetic oral, gastric and intestinal medium, equipped with enzymes to simulate gastrointestinal digestion. Factors

${ }^{1}$ Food, Nutrition, and Health, Faculty of Land \& Food Systems. 2205 East Mall, University of British Columbia, Vancouver, BC, V6T 1Z4, Canada. ' $S$ chool of Food and Biological Engineering, Jiangsu University, Zhenjiang, Jiangsu, 212013, P.R. China. ${ }^{\bowtie}$-mail: david.kitts@ubc.ca 


\begin{tabular}{|l|l|l|l|}
\hline Sample & As & Cd & Pb \\
\hline 1 & $15 \pm 3.0$ & $0.038 \pm 0.013$ & $20 \pm 2.00$ \\
\hline 2 & $15 \pm 1.0$ & $0.040 \pm 0.011$ & $18 \pm 1.00$ \\
\hline 3 & $17 \pm 2.0$ & $0.024 \pm 0.005$ & $6.1 \pm 0.40$ \\
\hline 4 & $16 \pm 3.0$ & $0.034 \pm 0.003$ & $5.8 \pm 0.90$ \\
\hline 5 & $16 \pm 2.0$ & $0.037 \pm 0.020$ & $6.4 \pm 1.00$ \\
\hline 6 & $4.1 \pm 1.0$ & $0.060 \pm 0.010$ & $8.48 \pm 1.09$ \\
\hline 7 & $3.8 \pm 0.2$ & $0.053 \pm 0.012$ & $8.52 \pm 1.21$ \\
\hline 8 & $3.8 \pm 0.3$ & $0.052 \pm 0.006$ & $8.05 \pm 0.19$ \\
\hline 9 & $3.8 \pm 0.2$ & $0.061 \pm 0.002$ & $8.73 \pm 0.56$ \\
\hline 10 & $4.1 \pm 0.4$ & $0.053 \pm 0.021$ & $8.45 \pm 0.28$ \\
\hline
\end{tabular}

Table 1. Total As, $\mathrm{Cd}$, and $\mathrm{Pb}$ content in mineral clay (ppm; mean $\pm \mathrm{SD}$ ).

such as metal species and speciation, as well as organic or inorganic components that co-exist in the matrix and which may act to sequester metals are known factors that will influence the extent of metal bioaccessibility ${ }^{12,13}$. Further risk assessment can be made by conducting in vitro bioavailability of the heavy metals following digestion using cultured Caco-2 cells, which assesses transfer behaviour and uptake of heavy metals ${ }^{14,15}$. Bioaccessibility and bioavailability assessment of heavy metals have formally been conducted to assess exposure from the soil, and water samples; agricultural crops and commodities such as, vegetables, seafood and natural health products ${ }^{14-19}$. The linear correlation reported between in vitro bioaccessibility assay for heavy metals and in vivo bioavailability data, reinforces its practical use to predict the exposure of heavy metals to humans ${ }^{16,20-22}$. The procedure also enables an alternative to animal testing methods that require protocals approved by animal ethics, and a need for rodent animal infrastructural facilities, whereas, in comparison, in vitro methods are less expensive, and rapid to complete.

Several standard methods are available to measure heavy metal bioaccessibility in mineral clay samples. Most often employed methods include the one-step USEPA method 1340; two-step methods that include the physiologically based extraction test (PBET) ${ }^{23}$ and the in vitro gastrointestinal method (IVG) ${ }^{22}$; and a three-step, Unified Bioaccessibility Research Group of Europe Method (UBM) ${ }^{18,19}$. The Bioaccessibility Research Group of Europe (BARGE) has developed UBM with the aim of producing a validated and standardized procedure to test heavy metal toxicity in the soil matrix ${ }^{24}$. The BARGE method has also been used to determine metals availability in fish and crab food sources ${ }^{25}$. The simulation consists of two phases; the gastric and gastrointestinal phase, where the gastric phase has samples treated with fluids that mimic the stomach fluid and the gastrointestinal phase where samples are digested with enzymes that simulate gastric and small intestine combined ${ }^{19,24}$. The USEPA method was initially established to measure $\mathrm{Pb}$ in soil samples and the same has never been tested on other matrices, including water, food and natural health products. Nevertheless, it should be noted that using different test methods will likely result in different estimates of bioaccessibility, due to a variety of variables that include medium $\mathrm{pH}$, the composition of digestion solution, the sample to solution ratio, and digestion time ${ }^{16,17}$.

After being released from the mineral matrix and becoming bioaccessible, there are numerous factors that can subsequently influence the bioavailability of mineral components. For example, factors such as solubility, interactions with other dietary ingredients, molecular transformations, presence or absence of cellular transporters, metabolism and the interaction with the gut microbiota, all can potentially influence the level of bioavailability ${ }^{26}$. Recently, cell culture has been used extensively as an in vitro method to assess the bioavailability of minerals present in natural health products. The Caco- 2 cell, a human colon adenocarcinoma cell line, has numerous morphological and biochemical characteristics that produce functional similarities to the small intestine when fully differentiated ${ }^{27-33}$. For these reasons, the Caco-2 cell has been shown to have usefulness to assess the in vitro bioavailability of heavy metal components in food products following gastric or gastrointestinal digestion ${ }^{15}$.

The current work seeks to evaluate the relative bioaccessibility of $\mathrm{As}, \mathrm{Cd}$ and $\mathrm{Pb}$ in mineral clay products using UBM and USEPA methods and to further estimate the in vitro bioavailability of these heavy metals using a Caco-2 monolayer permeability assay. This combination of bioaccessibility followed by bioavailability assessment will facilitate a greater understanding of factors that will impact on risk assessment potential of natural health products which contain therapeutic clay.

\section{Results and Discussion}

Total As, Cd, and $\mathrm{Pb}$ in clay samples. The total As, $\mathrm{Cd}$, and $\mathrm{Pb}$ concentrations in 10 batches of mineral clay samples are presented in Table 1. A wide range of heavy metal concentrations that included As (4-17 ppm); $\mathrm{Cd}(24-61 \mathrm{ppb})$ and $\mathrm{Pb}(6-20 \mathrm{ppm})$ were found. Results showed that As and $\mathrm{Pb}$ contents in clays collected from different sites (Sample 1-5 versus Sample 6-10) were quite variable. Indeed, factors specific to the sampling sites, such as geographical or environmental conditions, are often a major reason for high variability in heavy metal contents in soil and clay samples ${ }^{34,35}$. Moreover, variation in total heavy metal content, specifically for $\mathrm{Pb}$, was also observed from different collecting times made at the same site (Sample 1-2 and Sample 3-5); an observation that was not made for samples that contained As and Cd, respectively, collected from the same site, but at different times. We have no actual explanation for this difference at this time, except to speculate that relative differences in $\mathrm{pH}$ of individual clay aggregates sampled herein could have been a factor since low $\mathrm{pH}($ e.g. $\mathrm{pH}<5)$ characteristics are known to correspond to greater solubility of lead salts ${ }^{12}$. 


\begin{tabular}{|c|c|c|c|c|c|c|c|c|c|}
\hline \multirow[b]{3}{*}{ Samples } & \multirow{2}{*}{\multicolumn{3}{|c|}{ USEPA }} & \multicolumn{6}{|c|}{ UBM Method } \\
\hline & & & & \multicolumn{3}{|l|}{ UBM-G } & \multicolumn{3}{|l|}{ UBM-GI } \\
\hline & As & Cd & $\mathbf{P b}^{\mathbf{d}}$ & $\mathbf{A s}^{\mathrm{a}}$ & Cd & $\mathbf{P b}^{\mathrm{e}}$ & $\mathrm{As}^{\mathrm{b}}$ & $\mathrm{Cd}^{\mathrm{c}, \mathrm{g}}$ & $\mathbf{P b}^{\mathbf{f}}$ \\
\hline 1 & $6.62 \pm 1.20$ & $61.53 \pm 09.54$ & $15.24 \pm 01.39$ & $9.2 \pm 1.2$ & $63.1 \pm 8.1$ & $9.1 \pm 0.3$ & $9.1 \pm 1.4$ & $1.5 \pm 0.1$ & $1.4 \pm 0.5$ \\
\hline 2 & $6.96 \pm 0.27$ & $80.01 \pm 12.98$ & $18.51 \pm 01.20$ & $9.8 \pm 1.4$ & $67.2 \pm 13.1$ & $13.3 \pm 1.2$ & $9.1 \pm 1.3$ & $1.9 \pm 0.4$ & $1.1 \pm 0.3$ \\
\hline 3 & $7.89 \pm 0.23$ & $62.91 \pm 10.89$ & $1.43 \pm 0.21$ & $9.0 \pm 1.2$ & $47.1 \pm 13.9$ & $0.2 \pm 0.2$ & $8.8 \pm 1.2$ & n.a. & n.a. \\
\hline 4 & $7.08 \pm 0.39$ & $52.92 \pm 10.95$ & $1.99 \pm 0.45$ & $7.9 \pm 1.2$ & $39.3 \pm 4.7$ & n.a. & $7.9 \pm 1.6$ & n.a. & n.a. \\
\hline 5 & $5.65 \pm 0.05$ & $52.63 \pm 07.93$ & $0.88 \pm 0.23$ & $9.1 \pm 1.5$ & $45.3 \pm 7.7$ & n.a. & $8.5 \pm 0.9$ & n.a. & n.a. \\
\hline 6 & $8.03 \pm 0.17$ & $42.52 \pm 05.84$ & $1.73 \pm 0.04$ & $11.8 \pm 2.4$ & $44.2 \pm 15.0$ & $6.7 \pm 1.0$ & $9.4 \pm 0.5$ & $9.0 \pm 1.2$ & n.a. \\
\hline 7 & $8.33 \pm 1.02$ & $54.40 \pm 11.45$ & $2.37 \pm 0.08$ & $12.2 \pm 2.0$ & $56.7 \pm 11.7$ & $3.6 \pm 1.1$ & $10.2 \pm 1.3$ & $16.8 \pm 1.7$ & n.a. \\
\hline 8 & $8.04 \pm 0.43$ & $53.76 \pm 10.12$ & $2.23 \pm 0.03$ & $12.2 \pm 2.2$ & $55.8 \pm 5.5$ & $2.4 \pm 1.5$ & $10.3 \pm 1.4$ & $6.3 \pm 0.2$ & n.a. \\
\hline 9 & $7.09 \pm 0.58$ & $52.65 \pm 11.24$ & $2.20 \pm 0.56$ & $11.7 \pm 1.7$ & $50.9 \pm 4.0$ & $2.0 \pm 0.2$ & $9.0 \pm 1.2$ & $6.2 \pm 0.6$ & n.a. \\
\hline 10 & $7.25 \pm 0.92$ & $69.12 \pm 05.21$ & $2.14 \pm 0.08$ & $10.9 \pm 3.1$ & $51.5 \pm 13.3$ & $2.1 \pm 0.3$ & $9.4 \pm 1.1$ & $5.7 \pm 1.2$ & n.a. \\
\hline
\end{tabular}

Table 2. Bioaccessibility (\%) of $\mathrm{As}, \mathrm{Cd}$, and $\mathrm{Pb}$ measured by UBM and USEPA methods. Data are expressed as mean \pm standard deviation. *Bioaccessibilities of $\mathrm{As}, \mathrm{Cd}$, and $\mathrm{Pb}$ extracted with UBM-G method are significantly $(\mathrm{P}<0.05)$ greater than that of UBM-GI methods. ${ }^{\mathrm{a}, \mathrm{b}}$ Bioaccessibility of As extracted with UBM-G and UBM-GI methods is significantly different $(\mathrm{P}<0.05)$ between samples obtained from site 1 and site 2 . ${ }^{\mathrm{c} B i o a c c e s s i b i l i t y ~ o f ~ C d ~ e x t r a c t e d ~ w i t h ~ U B M-G I ~ m e t h o d s ~ i s ~ s i g n i f i c a n t l y ~ d i f f e r e n t ~ b e t w e e n ~}(\mathrm{P}<0.05)$ samples obtained from site 1 and site $2 .{ }^{\mathrm{d}-\mathrm{f}}$ Bioaccessibility of $\mathrm{Pb}$ extracted with different methods is significantly different $(\mathrm{P}<0.05)$ between site 1 samples obtained from different time periods. ${ }^{\mathrm{g}}$ Bioaccessibility of Cd extracted with UBM-GI methods is significantly different $(\mathrm{P}<0.05)$ between site 1 samples obtained from different time

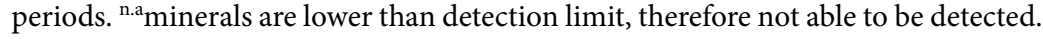

From the results presented in Table 1 and the recommended dosage of most commercially available mineral clay products (11-15 mg per lb body weight per day), we estimated that our results translate to ingesting a maximum of $45 \mu \mathrm{g} /$ day of As, $0.16 \mu \mathrm{g} /$ day of $\mathrm{Cd}$ and $52 \mu \mathrm{g} /$ day of $\mathrm{Pb}$ for a $175-\mathrm{lb}$ person if $100 \%$ is bioaccessible and bioavailable (Table 2). At these levels, As and $\mathrm{Pb}$, respectively, in mineral clay samples, are above the acceptable limit established by Health Canada, which prescribes a limit of $10 \mu \mathrm{g} / \mathrm{day}$ of As; $6 \mu \mathrm{g} / \mathrm{day}$ of Cd and $10 \mu \mathrm{g} / \mathrm{day}$ of $\mathrm{Pb}$, respectively, as acceptable limits for these metals in natural health products ${ }^{9}$. It is of interest, however, that the intakes mentioned above are lower than those reported in FDA regulations for heavy metals in seafood ${ }^{36}$, wherein the agency identified a "tolerable daily intake" for organic As to be $130 \mu \mathrm{g}$ per day and for Cd of $55 \mu \mathrm{g}$ per day, and a "provisional tolerable total intake level" for $\mathrm{Pb}$ to be $75 \mu \mathrm{g} /$ day.

Bioaccessibility of As, Cd, and Pb using USEPA method. In addition to determining the total heavy metal content in a formulated natural health product, obtaining information on the actual fraction of the heavy metals that are bioaccessible is required for risk assessment. This step involves elucidating the extent of release of heavy metals from clay samples after digestion and an accurate measurement of the metal in the digested fraction that is available to be absorbed.

The percent bioaccessibility of $\mathrm{As}, \mathrm{Cd}$, and $\mathrm{Pb}$ in mineral clay samples using the USEPA method is presented in Table 2. The results show some similarity to bioaccessibility data generated using the UBM methods, where $\mathrm{Cd}$ had relatively higher bioaccessibility compared to both $\mathrm{As}$ and $\mathrm{Pb}$, respectively. It is of interest that we found that the bioaccessibility of $\mathrm{Pb}$ collected on from Site 1 in August 2011 was greater $(\mathrm{P}<0.05)$ than those collected in February 2013. One explanation for this observation could be the difference in total metal content obtained from these particular samples. Looking closely at the As results, we note that As content was considerably higher $(\mathrm{P}<0.05)$ in Site 1 samples, compared with Site 2 samples, but there was no significant difference between the bioaccessibility of As from both sites. A different observation was obtained for the concentration of $\mathrm{Pb}$ at both sites which also produced significantly different $\mathrm{Pb}$ bioaccessibility results $(\mathrm{P}<0.05)$. Hence, although the bioaccessibility of As was not affected by the original concentration present, the same observation was not found with the $\mathrm{Pb}$ results. We suggest that factors that influence the bioaccessibility of minerals could be specific to the heavy metal of interest. Arsenic and bioaccessibility after USEPA digestion was $<9 \%$ and $<16 \%$, respectively, while the bioaccessibility for $\mathrm{Cd}$ was much higher, ranging from 42 to $80 \%$. This translates to the 175 -lb person, mentioned in the example above, having a maximum of $3.6 \mu \mathrm{g} /$ day of $\mathrm{As}, 0.10 \mu \mathrm{g} / \mathrm{day}$ of $\mathrm{Cd}$ and $8.75 \mu \mathrm{g} /$ day of $\mathrm{Pb}$ available for absorption (Table 3). This result is within the maximum tolerable bioaccessible limit set by Health Canada ${ }^{9}$ for these particular heavy metals.

Bioaccessibility of $\mathrm{As}, \mathrm{Cd}$, and $\mathrm{Pb}$ using UBM method. The total $\mathrm{As}, \mathrm{Cd}$ and $\mathrm{Pb}$ concentration in extraction fluids were measured, and contents in the preparation blanks were calculated based on the concentration in the extraction fluids. Saliva, gastric, bile and duodenal fluids contained $0.078,0.917,0.654,1.272 \mathrm{ng} /$ $\mathrm{mL}$ As, respectively. Similarly, $\mathrm{Pb}$ content in the same digestion fluids were $0.347,0.575,0.446$ and $0.236 \mathrm{ng} / \mathrm{mL}$, respectively. These results corresponded to 0.017 and $0.066 \mu \mathrm{g} / \mathrm{g}$ As, and 0.036 and $0.056 \mu \mathrm{g} / \mathrm{g} \mathrm{Pb}$ in the gastric and gastrointestinal digestion fluids, respectively. Cadmium was not detectable in the extraction fluids. Unlike the results obtained from the USEPA method, total As content was higher in Site 2 compared to Site 1 using both UBM digestion methods (Table 2). The underlying reasons for this observation is likely attributed to the differences in geographic conditions, which can impact the extraction efficiencies for different heavy metals. However, we did determine that in general, the bioaccessibility of $\mathrm{As}, \mathrm{Cd}$, and $\mathrm{Pb}$ after gastric digestion was higher than 


\begin{tabular}{|c|c|c|c|c|c|c|c|c|c|c|c|c|}
\hline \multirow[b]{3}{*}{ Samples } & \multicolumn{3}{|c|}{$\begin{array}{l}\text { Initial total heavy } \\
\text { metal content }{ }^{\mathrm{a}} \\
(\mu \mathrm{g} / \text { day })\end{array}$} & \multicolumn{3}{|c|}{$\operatorname{USEPA}^{\mathrm{a}}(\boldsymbol{\mu g} / \mathrm{day})$} & \multicolumn{6}{|c|}{$\mathrm{UBM}^{\mathrm{a}}(\mu \mathrm{g} /$ day $)$} \\
\hline & \multirow[b]{2}{*}{ As } & \multirow[b]{2}{*}{ Cd } & \multirow[b]{2}{*}{$\mathrm{Pb}$} & \multirow[b]{2}{*}{ As } & \multirow[b]{2}{*}{ Cd } & \multirow[b]{2}{*}{$\mathrm{Pb}$} & \multicolumn{3}{|c|}{ UBM-G } & \multicolumn{3}{|c|}{ UBM-GI } \\
\hline & & & & & & & As & Cd & $\mathrm{Pb}$ & As & Cd & $\mathrm{Pb}$ \\
\hline 1 & 40 & 0.099 & 52 & 2.6 & 0.061 & 8.00 & 3.68 & 0.062 & 4.70 & 3.6 & 0.001 & 0.7 \\
\hline 2 & 40 & 0.105 & 48 & 2.7 & 0.084 & 8.75 & 3.92 & 0.070 & 6.40 & 3.6 & 0.002 & 0.5 \\
\hline 3 & 45 & 0.063 & 16 & 3.6 & 0.040 & 0.23 & 4.05 & 0.030 & 0.03 & 4.0 & n.a. & n.a. \\
\hline 4 & 42 & 0.090 & 15 & 3.0 & 0.047 & 0.30 & 3.32 & 0.035 & n.a. & 3.3 & n.a. & n.a. \\
\hline 5 & 42 & 0.097 & 17 & 2.3 & 0.051 & 0.14 & 3.82 & 0.044 & n.a. & 3.5 & n.a. & n.a. \\
\hline 6 & 11 & 0.157 & 22 & 0.8 & 0.067 & 0.39 & 1.30 & 0.067 & 1.48 & 1.0 & 0.014 & n.a. \\
\hline 7 & 10 & 0.139 & 22 & 0.8 & 0.076 & 0.53 & 1.22 & 0.079 & 0.80 & 1.0 & 0.023 & n.a. \\
\hline 8 & 10 & 0.136 & 21 & 0.8 & 0.073 & 0.47 & 1.22 & 0.076 & 0.50 & 1.0 & 0.009 & n.a. \\
\hline 9 & 10 & 0.160 & 23 & 0.7 & 0.084 & 0.50 & 1.17 & 0.081 & 0.46 & 0.9 & 0.010 & n.a. \\
\hline 10 & 11 & 0.139 & 22 & 0.8 & 0.100 & 0.48 & 1.20 & 0.071 & 0.47 & 1.0 & 0.008 & n.a. \\
\hline
\end{tabular}

Table 3. Maximum concentration of available heavy metal allowed for absorption as based on the recommended daily dose of mineral clay samples ${ }^{9}$ a Heavy metal available ( $\left.\mu \mathrm{g} / \mathrm{day}\right)$ to a to $175 \mathrm{lb}$ person before and after digestion (based on the recommended dose of 11-15 mg mineral clay/ lb body/day).

that obtained with gastrointestinal digestion; $\mathrm{Cd}$ and $\mathrm{Pb}$ showing a much greater difference compared with As. This difference can be attributed to the acidic conditions used for gastric digestion, which not only enabled the release of the minerals from the clay matrix but also provided the low $\mathrm{pH}$ required for optimal solubility of metal ions. Our result indicates that bioaccessibility of As reached around $10 \%$ with the gastric digestion, while the bioaccessibility for Cd was much higher, ranging from 40 to $70 \%$. Hence, using the UBM-G method, the same 175-lb person model would require a maximum intake of 4, 0.08, and 6.4 $\mu \mathrm{g} / \mathrm{day}$, respectively (Table 3) for As, Cd and $\mathrm{Pb}$ in order to be bioavailable. These estimates meet the maximum tolerable limit for these heavy metals set by Health Canada9 .

A different result was obtained using the UBM-GI assay, where the bioaccessibility of $\mathrm{Cd}$ and $\mathrm{Pb}$ decreased dramatically in the gastrointestinal digestion phase ( $<17 \%$ of $\mathrm{Cd},<1.5 \%$ of $\mathrm{Pb}$ ), compared to that observed using only gastric digestion. Lower bioaccessibility of these $\mathrm{Cd}$ and $\mathrm{Pb}$ metals corresponded to the increased $\mathrm{pH}$ conditions ( $\mathrm{pH}$ 8.0), which were used to mimic the gastrointestinal digestion, compared to the low $\mathrm{pH}$ gastric digestion. The lower apparent bioaccessibility of these metals from the clay matrix is attributed to the poor solubility at neutral to alkaline conditions. This was not observed for As using the UBM-GI bioaccessibility digestion, where little change occurred and recovery remained at approximately $10 \%$.

Hence, the maximum bioaccessibility of $4 \mu \mathrm{g} /$ day for As, $0.02 \mu \mathrm{g} / \mathrm{day}$ for $\mathrm{Cd}$, and $0.7 \mu \mathrm{g} / \mathrm{day}$ for Pb (Table 3) when translated to our 175-lb subject is within the tolerable limits, according to Health Canada regulations ${ }^{9}$. Former studies conducted by other researchers using medicinal clay samples (Natural Health Product) ${ }^{37,38}$ reported similar results. It should also be noted, that the total heavy metal concentrations in many of these former studies were also reduced by $\sim 99 \%$ after gastric/gastrointestinal digestion. Koch et al. ${ }^{37}$ demonstrated that only $4 \%$ of the total As content in "Niu Huang Jie Du Pian pills (Natural Health Supplement)" was bioaccessible after UMB-GI digestion. They also validated their findings by measuring heavy metal excretion in urine. More recently, bioaccessibility measure of As content in 42 medicines, reported only 12 preparations were bioaccessible, and only one had a bioaccessible total inorganic As concentration that exceeded the safe limit (USEPA Oral RfD $)^{38}$.

Comparison of bioaccessibility of As, Cd, and Pb using UBM and USEPA method. The UBM method is an internationally recognized method for testing heavy metal bioaccessibility in soil matrices, but it has not yet received acceptance for similar use by Health Canada's Natural and Non-prescription Health Products Directorate (NNHPD) for assessing heavy metal bioaccessibility in natural health and food products ${ }^{9}$. The NNHPD recommends either the use of acid hydrolysis (with a strong acid such as $\mathrm{HNO}_{3}$ ) followed by measurements on ICP-MS or ICP-AES, or a colorimetric method (e.g. FCC) for detecting heavy metals in finished natural health products. Similar approaches are approved by other regulatory agencies for heavy metal testing in natural health products ${ }^{23,39}$. The UBM method is based on the concept that metals bound in different soil types that have a mineral matrix will solubilize differently in the GI tract, thus influencing bioavailability. Only the soluble or the bioaccessible fraction of the metal in the GI tract is made available for absorption before ultimately reaching the systemic circulation ${ }^{19}$. The non-soluble fraction of the metal is expected to be excreted in its bound form in the feces. Although researchers have indicated that this method could be used for an exposure assessment in food products such as fruits, vegetables and natural health products ${ }^{25,40}$.

Our results indicate that Cd bioaccessibility using the USEPA method agreed with the UBM-G analysis which reflects only the gastric digestion phase. The limitation of using the USEPA method to predict heavy metal bioaccessibility from natural health products taken orally is that it is a generic single-step extraction procedure, while, UBM-GI simulates digestion from gastric and gastrointestinal phases. Based on these observations, we conclude that the UBM-GI method is a better procedure to estimate bioaccessibility since it more closely mimics the conditions of the human GI tract. The lower solubility of $\mathrm{Cd}$ and $\mathrm{Pb}$ due to the alkaline conditions present with the total gastrointestinal digestion method apparently also lead to lower absolute values for bioaccessibility. When extrapolating this observation to an in vivo situation, the insoluble heavy metals, such as $\mathrm{Cd}$ and $\mathrm{Pb}$, would not be 


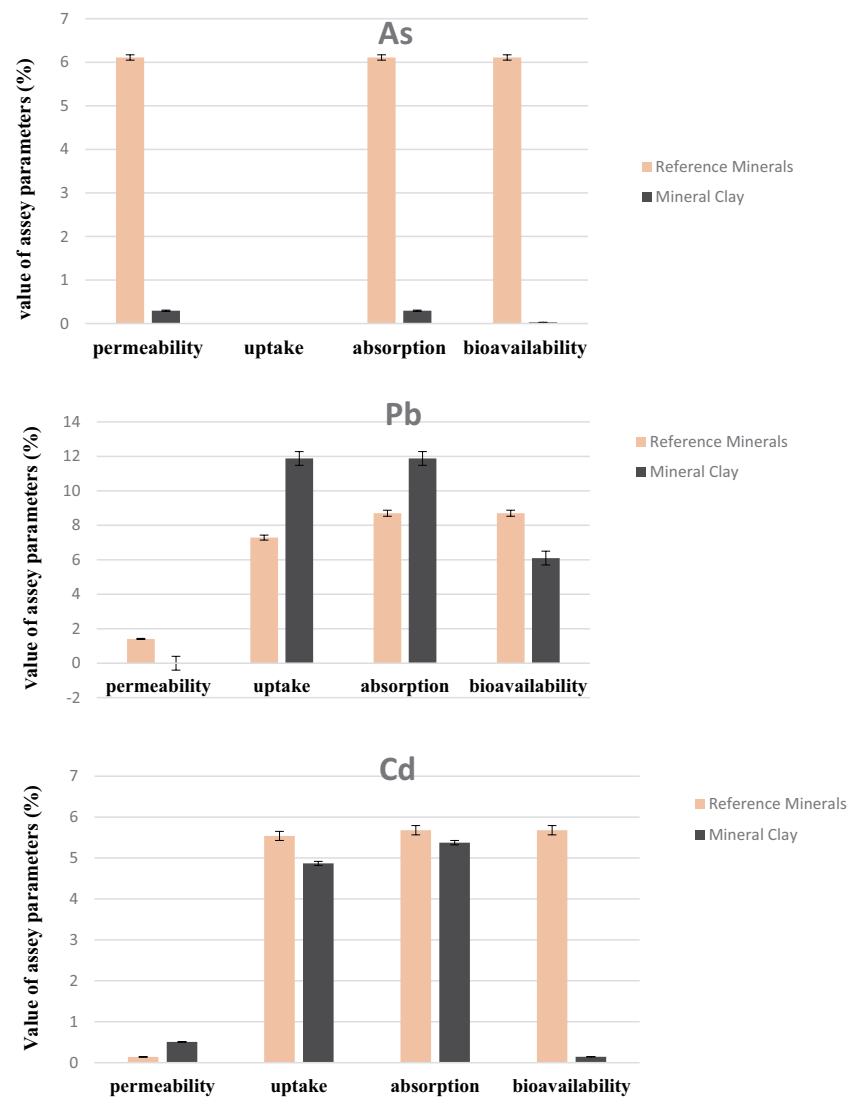

Figure 1. Representation of bioavailability (\%) of $\mathrm{As}, \mathrm{Pb}$ and $\mathrm{Cd}$ in reference mineral and mineral clay. Measures of bioavailability are mean values derived in triplicate from a single Caco- 2 cell culture. A total of 3 experiments were performed all showing similar trends in terms of individual metal transport characteristics.

expected to be free for absorption and thus excreted in feces. Other factors to consider affecting bioaccessibility of $\mathrm{Cd}$ and $\mathrm{Pb}$ from clay samples could be such factors as the presence of phytochelatins, metal species and its speciation $^{13,15}$.

Bioavailability of $\mathrm{As}, \mathrm{Cd}$, and $\mathrm{Pb}$. Prior to conducting the Caco-2 permeability assay, we determined the potential toxicities of the heavy metal preparations using MTT-redox assay for cell viability and relative epithelial resistance $(\%, \mathrm{RES})$ to evaluate the effect of mineral clay digest on the integrity of cell monolayers. MTT results were greater than $90 \%$ control indicating that no toxicity existed at the concentrations used in this experiment. Similarly, the TEER value for all samples tested in this study was greater than $90 \%$, thus indicating that the mineral clay digest did not affect the integrity of Caco-2 monolayer.

Figure 1 shows the bioavailability of $\mathrm{As}, \mathrm{Cd}$, and $\mathrm{Pb}$ in both reference form as well as from mineral clay digest samples, respectively. Very low permeability values obtained for $\mathrm{As}, \mathrm{Pb}$ and $\mathrm{Cd}$ were equivalent to $0.295 \%$, $0.078 \%$, and $0.506 \%$, respectively. The uptake of As was not detectable in all samples whereas, for $\mathrm{Pb}$ and $\mathrm{Cd}$ the values were $<12 \%$ for all samples. Overall, the bioavailability of Cd was $6.1 \%$, while for Pb it was $0.144 \%$. Previous studies have shown that bioavailability of $\mathrm{Pb}$ in the mineral matrix is dependent on its association with carbonate complexes which enhances bioaccessibility ${ }^{17}$. Mineral analysis of clay samples has listed the presence of many divalent ions, such as calcium, magnesium, and iron, which are known to immobilize arsenate and lower its solubility ${ }^{13}$. Another parameter to consider for bioaccessibility is the residence time of the matrix in the gastric compartment. The greater the residence time of the matrix in the gastric compartment, the more efficient the extraction. Overall, our results indicated that the bioavailability of $\mathrm{As}, \mathrm{Cd}$, and $\mathrm{Pb}$ in mineral clay samples ranged from very low to non-detectable levels, which suggests a low risk to human health.

Correlation between bioaccessibility and bioavailability. In order to use in vitro bioaccessibility assays (such as UBM and USEPA) as a surrogate measurement of heavy metal dietary exposure, other works have used correlations to show the extent of agreement between 'in vitro bioaccessibility and in vitro bioavailability assays $^{20,41,42}$. This approach has been used by researchers interested in various oral preparations that include heavy metals in mineral clay complexes and nutrients in food or natural health products ${ }^{22,43,44}$. In the present study, we present correlations between different bioaccessibility essays (UBM-G $v s$ UBM-GI and UBM $v s$ USEPA) to interpret bioaccessibility results derived from different assay methodology. The bioaccessibility of As using UBM-GI was significantly correlated with UBM-G $(r=0.865, \mathrm{P}<0.001)$. However, no correlation was established for Cd 
and $\mathrm{Pb}$ using the UBM gastric and gastrointestinal digestion methods. This was attributed to the very low to nondetectable bioaccessibility values obtained for $\mathrm{Cd} \& \mathrm{~Pb}$ concentrations using the UBM-GI assay.

On the other hand, As bioaccessibility measured by the USEPA method was correlated with the UBM-G $(\mathrm{r}=0.601, \mathrm{P}<0.01)$ and UBM GI $(\mathrm{r}=0.643, \mathrm{P}<0.01)$ assays. We conclude therefore that there is good potential for using the BARGE method for estimating heavy metal detection of mineral clay products when prepared for gastrointestinal digestion. We also examined if correlations existed between bioaccessibility (UBM-G) and bioavailability, using Caco- 2 cell methodology. Cadmium bioaccessibility was significantly $(\mathrm{r}=0.798, \mathrm{P}<0.01)$ correlated with in vitro bioavailability, measured using the Caco-2 monolayer assay. This was not the case for $\mathrm{Pb}$, which we attribute to the fact the bioavailability values of $\mathrm{Pb}$ were non-detectable due to poor solubility.

\section{Conclusion}

The results of our comparison of using three different bioaccessibility assays, showed that only $10-16 \%$ of the original $\mathrm{As}$ and $\mathrm{Pb}$ content present in mineral clay complexes was free for absorption. On the other hand, the bioaccessibility values for Cd were relatively high; however, it should be noted that the initial Cd content in the clay samples was comparatively low (24-61ppb). This therefore equates to $0.16 \mu \mathrm{g} /$ day of Cd consumption by a $175-\mathrm{lb}$ adult consuming maximum prescribed doses of mineral clay product. This estimate shows that the initial $\mathrm{Cd}$ content in mineral clay is below the total minimum $\mathrm{Cd}$ limit established by Health Canada $(<6.0 \mu \mathrm{g} / \mathrm{day})$. The UBM and USEPA bioaccessibility methods were compared, and the UBM method was found to relatively more effective in mimicking the human stomach digestion process on this product matrix. Based on these observations, we support using the UBM method for heavy metal bioaccessibility in natural health products.

Extending this study to include the bioavailability of these heavy metals using the Caco-2 monolayer cell culture assay revealed that all metals, after correction for bioaccessibility, produced very low to non-detectable permeability estimates. It can be concluded from these combined in- vitro bioaccessibility and bioavailability results, that a very low probability of risk associated with consumption of these mineral clays exists if the recommended usage specifications (11-15 mg per lb body weight) is followed.

\section{Methods}

Materials. All reagents used were of analytical grade. All solutions were prepared using ultra-high pure (UHP) $18 \Omega$ water. All laboratory ware was soaked for $24 \mathrm{~h}$ in an acid bath containing $10 \%(\mathrm{v} / \mathrm{v})$ nitric acid and then rinsed with UHP water. Concentrated hydrochloric acid $\left(12 \mathrm{~mol} \mathrm{~L}^{-1}\right), \mathrm{HNO}_{3} 69 \%, \mathrm{NaCl}, \mathrm{NH}_{4} \mathrm{Cl}$, anhydrous $\mathrm{Na}_{2} \mathrm{SO}_{4}, \mathrm{CaCl}_{2} \cdot 2 \mathrm{H}_{2} \mathrm{O}, \mathrm{NaHCO}_{3}$, anhydrous $\mathrm{D}(+)$-glucose, sodium arsenate dibasic heptahydrate, cadmium acetate and lead acetate trihydrate were obtained from Fisher Scientific. d-glucuronic acid, Pancreatin (pig), pepsin (pig), Bovine serum albumin (BSA), $\mathrm{KSCN}, \mathrm{NaH}_{2} \mathrm{PO}_{4}$, mucin (pig), D-glucosamine hydrochloride, lipase (pig), $\alpha$-amylase (Bacillus species), urea and bile salts (bovine), modified eagle medium (DMEM) containing $4.5 \mathrm{~g} / \mathrm{L}$ glucose, penicillin-streptomycin solution (10,000 units penicillin and $10 \mathrm{mg}$ streptomycin per $\mathrm{mL}$ ), and Hank's Balanced Salt Solution (HBSS) and glycine were obtained from Sigma-Aldrich (St. Louis, MO, USA). $\mathrm{KH}_{2} \mathrm{PO}_{4}$, $\mathrm{MgCl}_{2} \cdot 6 \mathrm{H}_{2} \mathrm{O}, \mathrm{KCl}$, and uric acid were obtained from VWR. Caco-2 cells (HTB-37 ${ }^{\mathrm{TM}}$ ) were purchased at passage 18 from the American Type Culture Collection (ATCC, Manassas, VA, USA). Fetal bovine serum and trypsinEDTA were purchased from Invitrogen (Burlington, ON, Canada).

Collection of mineral clay samples. The clay samples were collected at different times from 2 locations at Sierra Mountains (USA). The specific sample details (year, month, location) are shown in Table 4 . The clay samples were air-dried, disaggregated sieved $(2 \mathrm{~mm})$ to remove large pieces, and then screened to exclude particles greater than $250 \mu \mathrm{m}$. Samples were kept at room temperature in a sealed container until three-phase (saliva/ gastric/gastrointestinal) in vitro digestion.

Instrumentation. Elemental analysis was carried out using an inductively coupled plasma mass spectrometer (ICP-MS, Agilent 8900 Triple Quadrupole (QQQ) ICP-MS) coupled to a cross-flow nebulizer. The operating parameters of the ICP-MS instrument were as follows: Sampling/skimmer cones $=\mathrm{Pt}$; RF power $=1100 \mathrm{~W}$; Signal measurement $=$ Peak Hopping; Detector voltage $=$ Pulse $1250 \mathrm{~V}$; Gas flow rate; Main 15.0 - L/min; Auxiliary $1.2 \mathrm{~L} / \mathrm{min}$; Nebulizes - $1.0 \mathrm{~L} / \mathrm{min}$. These measurements were converted to $\mu \mathrm{g} / \mathrm{L}$ by referencing a calibration curve.

Total heavy metal content of original clay sample. Total As, $\mathrm{Cd}$ and $\mathrm{Pb}$ concentrations in clay samples were analyzed using ICP-MS after digestion with $\mathrm{HNO}_{3}{ }^{45}$. Approximately $0.2 \mathrm{~g}$ of mineral clay samples were mixed with $6 \mathrm{ml}$ of $\mathrm{HNO}_{3}, 2 \mathrm{ml}$ of $\mathrm{HCL}$ and $2 \mathrm{ml}$ of hydrofluoric for the simultaneous extraction of metals. The solution was digested by microwave using the following procedure: heated to $120^{\circ} \mathrm{C}$ in 8 minutes and holding $3 \mathrm{~min}$; raising the temperature to $150^{\circ} \mathrm{C}$ maintaining $5 \mathrm{~min}$; increase the temperature to $190^{\circ} \mathrm{C}$ keeping $35 \mathrm{~min}$. After cooling, $2 \mathrm{ml}$ of $\mathrm{H}_{2} \mathrm{O}_{2}$ was added to the digested mixture then heated at $140^{\circ} \mathrm{C}$ in a heating block until the residue solution left about $1 \mathrm{~mL}$. Finally, the solution was transferred into 50 volumetric flasks, brought to volume with water and mixed fully. The determination of metals was performed by ICP-MS with internal standard method and standard addition method. Multielement Calibration Standard 3 diluted to $10 \mathrm{mg} / \mathrm{L}$ (in 5\% HNO3) was used for instrument calibration. Minimal detection limits for As, Cd and Pb were, $0.1 \mu \mathrm{g} / \mathrm{L} ; 0.01 \mu \mathrm{g} / \mathrm{L}$; $0.02 \mu \mathrm{g} / \mathrm{L}$, respectively.

In vitro bioaccessibility using USEPA method. Bioaccessibility measurements of heavy metals using the USEPA method were performed according to details outlined in the USEPA method $1340^{46}$. Mineral clay samples ( 10 batches of samples, duplicate, $1.0 \mathrm{~g}$ each) were weighed into high-density polyethylene (HDPE) bottles containing $100 \mathrm{~mL}$ extraction fluid; consisting of $0.4 \mathrm{~mol} / \mathrm{L}$ glycine (free base, reagent-grade glycine in deionized water), adjusted to a $\mathrm{pH}$ of $1.50 \pm 0.05$ using $0.5 \% \mathrm{HCl}$. Samples were pre-heated to $37 \pm 2{ }^{\circ} \mathrm{C}$ followed by 


\begin{tabular}{|c|c|c|c|c|}
\hline Sample No. & $\begin{array}{l}\text { Sample } \\
\text { collection Site }\end{array}$ & Sample Code & Month & Year \\
\hline 1 & Site - 1 & \multirow{2}{*}{ S1-1 } & August & 2011 \\
\hline 2 & & & August & 2011 \\
\hline 3 & & \multirow{2}{*}{$\mathrm{S} 1-2$} & February & 2013 \\
\hline 4 & & & \begin{tabular}{|l|} 
February \\
\end{tabular} & 2013 \\
\hline \multirow[t]{2}{*}{5} & & $\begin{array}{l}\mathrm{S} 1-3 \\
\mathrm{~S} 1-4\end{array}$ & \multirow[t]{2}{*}{ February } & \multirow[t]{2}{*}{2013} \\
\hline & & S S1-5 & & \\
\hline 6 & Site -2 & \multirow[t]{2}{*}{ [ S2-1 } & October & 2014 \\
\hline 7 & & & October & 2014 \\
\hline 8 & & \multirow{2}{*}{ S2-2 } & October & 2014 \\
\hline 9 & & & October & 2014 \\
\hline \multirow[t]{2}{*}{10} & & $\begin{array}{l}\text { S2-3 } \\
\text { S2-4 }\end{array}$ & \multirow[t]{2}{*}{ October } & \multirow[t]{2}{*}{2014} \\
\hline & & S2-5 & & \\
\hline
\end{tabular}

Table 4. Sample information of mineral clay.

extraction, which involved rotating the samples at $30 \pm 2 \mathrm{rpm}$ for one hour. An aliquot $(40 \mathrm{~mL})$ of the supernatant was filtered through a $0.45 \mu \mathrm{m}$ cellulose filter followed by heavy metal analysis using ICP-MS as described above.

In vitro bioaccessibility measurement using UBM method. Preparation of gastric and intestinal solutions. Gastric and gastrointestinal fluids were prepared according to the procedure described by Wragg et al. ${ }^{19}$ To prepare $1000 \mathrm{ml}$ of simulated saliva fluid, amylase $(145 \mathrm{mg})$, mucin $(50 \mathrm{mg})$, and Uric Acid $(15 \mathrm{mg})$ were added in a 2 L HDPE screw top bottle. Simultaneously the inorganic $(500 \mathrm{ml})$ and organic saliva phase $(500 \mathrm{ml})$ reagents were added together and mixed thoroughly ${ }^{19}$. The $\mathrm{pH}$ of the simulated saliva fluid was adjusted to $6.5 \pm 0.5$. To prepare the simulated gastric fluid ( $1 \mathrm{~L}$, Bovine Serum Albumin $(1000 \mathrm{mg})$, mucin $(3000 \mathrm{mg})$ and pepsin $(1000 \mathrm{mg})$ were added together into a $2 \mathrm{~L}$ HDPE screw-top bottle, and mixed thoroughly. The $\mathrm{pH}$ of the simulated saliva fluid was adjusted to 1.0, using HCL. To prepare $1 \mathrm{~L}$ simulated duodenal fluid, $\mathrm{CaCl}_{2}(200 \mathrm{mg})$, bovine serum albumin $(1000 \mathrm{mg})$, pancreatin $(3000 \mathrm{mg})$ and lipase $(500 \mathrm{mg})$ were added in a $2 \mathrm{~L}$ HDPE screw-top bottle and mixed thoroughly. The $\mathrm{pH}$ of the simulated duodenal fluid was adjusted to $7.4 \pm 0.2 \mathrm{using} 0.5 \mathrm{M} \mathrm{NaOH}$. The bile fluid $(1 \mathrm{~L})$ was prepared by adding $\mathrm{CaCl}_{2}(222 \mathrm{mg})$, bovine serum albumin $(1800 \mathrm{mg})$ and bile $(6000 \mathrm{mg})$ to a $2 \mathrm{~L} \mathrm{HDPE}$ screw-top bottle and mixed thoroughly ${ }^{19}$. The $\mathrm{pH}$ of the simulated duodenal fluid was $\mathrm{pH} 8.0 \pm 0.2$ and the final $\mathrm{pH}$ of gastric and gastrointestinal phases were $1.2-1.4$ and $6.3 \pm 0.5$, respectively.

Determination of heavy metal bioaccessibility using UBM digestion method. The digestion procedures were performed based on the method described by Wragg et al. ${ }^{18}$ Briefly, for gastric phase digestion, samples of mineral clay ( 10 batches of $0.6 \mathrm{~g}$ samples in duplicate) were mixed with $9.0 \mathrm{~mL}$ of saliva solution ( $\mathrm{pH} 6.5 \pm 0.5)$ in $50 \mathrm{~mL}$ falcon tubes and shaken manually for $30 \mathrm{~s}$; followed by mixing with $13.5 \mathrm{~mL}$ of gastric solution $(\mathrm{pH} 0.9-1.0)$ using a rotator set at $30 \pm 2 \mathrm{rpm}$ for $1 \mathrm{~h}$ in a $37^{\circ} \mathrm{C}$ incubator. This represented the gastric phase fluid, and heavy metals were analyzed from this fluid after centrifugation at $4500 \times \mathrm{g}$ for 15 minutes and a 10 times dilution with $1 \% \mathrm{HNO}_{3}(\mathrm{v} / \mathrm{v})$ using ICP-MS. For the gastrointestinal phase, an additional $9 \mathrm{~mL}$ of simulated bile fluid ( $\mathrm{pH}$ $8.0 \pm 0.2)$ and $27 \mathrm{~mL}$ of simulated duodenal fluid $(\mathrm{pH} 7.4 \pm 0.2)$ were added to the gastric phase fluid. The mixture was shaken at $30 \pm 2 \mathrm{rpm}$ for another $4 \mathrm{~h}$ in a $37^{\circ} \mathrm{C}$ incubator and then centrifuged at $4500 \times \mathrm{g}$ for 15 minutes, followed by 10 times dilution with $0.5 \% \mathrm{HCl}(\mathrm{v} / \mathrm{v})$. Final samples were then analyzed for heavy metal bioaccessibility using ICP-MS.

Ten clay samples were digested and analyzed using the method described above. The bioaccessibility of metals present in mineral clay samples are defined as:

$$
\text { Bioaccessibility }(\%)=\frac{\text { Metal content in aqueous phase }}{\text { Metal content in original sample }} \times 100
$$




$$
\text { Bioaccessible content }(p p m)=\text { Initial heavy metal in clay }(p p m) \times \frac{\text { Bioaccessibility }(\%)}{100}
$$

In vitro bioavailability measurement using Caco-2 cells. Caco- 2 cell culture. The in vitro bioavailability of heavy metals was analyzed using Caco-2 cell culture ${ }^{33,47}$. Briefly, Caco-2 cells (HTB-37, ATCC) were cultured in Dulbecco's Modified Eagle Medium (DMEM) containing 4.5 g/L glucose (Sigma, St. Louis, MO, USA) supplemented with $10 \%$ fetal bovine serum (FBS) (Invitrogen, Canada), $100 \mu \mathrm{g} / \mathrm{ml}$ of penicillin and $100 \mu \mathrm{g} / \mathrm{ml}$ of streptomycin at $37^{\circ} \mathrm{C}$ under a $5 \% \mathrm{CO}_{2}$ atmosphere. The medium was changed every $2-3$ days, and the cells were subcultured weekly by trypsin-EDTA treatment. Twenty-one day old, differentiated, Caco-2 cells were seeded onto 6-well translucent Transwell inserts $(24 \mathrm{~mm}$ diameter, $0.4 \mu \mathrm{m}$ pore size, high-density polyethylene terephthalate membrane, BD Biosciences, San Jose, CA, USA) at a density of $2.5 \times 10^{5} \mathrm{cells} / \mathrm{cm}^{2}$ and allowed to grow for 3 weeks. All the cells used in this study were between 22 and 29 passages. The toxicity potential of heavy metal samples to Caco- 2 cells was conducted using MTT redox assay ${ }^{47}$. Transepithelial electrical resistance (TEER) values were measured using a volt-ohmmeter (Millicell ${ }^{\circledR}$ ERS, Millipore, Bedford, MA, USA) to assess the integrity of the monolayers.

In vitro bioavailability measurement. Gastrointestinal digested solutions were boiled for 5 min to deactivate the enzymes followed by adjustment to $\mathrm{pH} 7.0$ using $10 \mathrm{~N} \mathrm{NaOH}$. Sodium arsenate dibasic heptahydrate (As), cadmium acetate $(\mathrm{Cd})$, lead acetate trihydrate $(\mathrm{Pb})$ were used as references to test the bioavailability of free minerals. Samples were dissolved in $18 \Omega \mathrm{H}_{2} \mathrm{O}$ and diluted in HBSS to the concentration of $1,0.1$, and $1 \mu \mathrm{g} / \mathrm{mL}$, respectively. The digested clay, and reference-heavy metal samples were sterilized through filtration followed by three times dilution in HBSS. For heavy metal permeability measurements, the culture medium in the insert or well was first removed and $1.5 \mathrm{ml}$ of the diluted digested aqueous solution, or reference samples, were added to the apical side and $2.6 \mathrm{~mL}$ HBSS was added to the basolateral chamber. The cell cultures were incubated at $37^{\circ} \mathrm{C}, 5 \% \mathrm{CO}_{2}$ and $95 \%$ relative humidity for $2 \mathrm{~h}$. An aliquot of the solution from the basolateral chamber was collected for heavy metal analysis. Caco-2 monolayers were then washed three times with phosphate-buffered saline (PBS) and incubated with $1 \mathrm{~mL}$ trypsin-EDTA to collect the cells. Cells were aspired and then centrifuged for $10 \mathrm{~min}$ at a speed of $1000 \times \mathrm{g}$ and digested with $1 \mathrm{~mL}$ concentrated $\mathrm{HNO}_{3}$ for $4 \mathrm{~h}$ at $110^{\circ} \mathrm{C}$ and left overnight at room temperature. Then $2 \mathrm{~mL}$ of $18 \Omega \mathrm{H}_{2} \mathrm{O}$ was added into the digested cells. As, $\mathrm{Cd}$ and $\mathrm{Pb}$ present in Caco- 2 cell digest and sampled from the bottom compartment of the insert, representing the basolateral solution were analyzed using ICP-MS according to the methods outlined above. Three experiments were conducted using Caco- 2 cells prepared at the same stage of development and cell density and samples were tested in triplicate for each experiment. All three experiments showed similar trends for each measure of bioavailability. A representative result of the three experiments was presented.

Parameter measurements used to assess the bioavailability of heavy metals present in mineral clay samples are defined as:

$$
\begin{gathered}
\text { Permeability }(\%)=\frac{\text { Heavy metal in basolateral chamber }}{\text { Heavy metal in aqueous phase added }} \times 100 \\
\text { Uptake }(\%) \text { by cells }=\frac{\text { Heavy metal in cells }}{\text { Heavy metal in aqueous phase added }} \times 100 \\
\text { Absorption }(\%)=\text { Permeability }(\%)+\text { uptake }(\%) \\
\text { Bioavailability }(\%)=\text { bioaccessibility }(\%) \times \text { absorption }(\%)
\end{gathered}
$$$$
\text { Bioavailable content }(p p m)=\text { Initial heavy metal in clay }(p p m) \times \frac{\text { Bioavailability }(\%)}{100}
$$

Samples collected from bioaccessible fractions and monolayer Caco-2 cells were analyzed by ICP-MS.

Statistical analysis. All assays were conducted at least in duplicate, and significant differences were established between means at $\mathrm{P}<0.05$. The different bioaccessibility (\%) between sites were assessed using student's t-test. Correlations were also determined using statistical tools (Minitab Statistical Software Version 16, Minitab Inc., State College, PA, USA).

\section{Data availability}

The datasets generated during and/or analyzed during the current study are available from the senior author on reasonable request.

Received: 27 September 2018; Accepted: 29 April 2020;

Published online: 01 June 2020 


\section{References}

1. Carretero, M. I. et al. Clay minerals and their beneficial effects upon human health. A review. Applied Clay Sci. 21, 155-163 (2002).

2. Johns, T. \& Duquette, M. Detoxification and mineral supplementation as functions of geophagy. Amer. J. Clin. Nutri. 53(2), 448-56 (1991).

3. Miller, M. J. et al. Early relief of osteoarthritis symptoms with a natural mineral supplement and a herbomineral combination: a randomized controlled trial [ISRCTN38432711]. J Inflam. 2, 1 (2005).

4. Miller, M. J., Ahmed, S., Bobrowski, P. \& Haqqi, T. M. Suppression of human cartilage degradation and chondrocyte activation by a unique mineral supplement (Sierrasil ${ }^{\mathrm{TM}}$ ) and a cat's claw extract, vincaria ${ }^{\circledR}$. J. Amer. Nutraceut.l Assoc. 7(2), 32-39 (2004).

5. Bentley, M. United states patent No. US 7910136B2 (2011).

6. Evans, M., Wilson, D. \& Guthrie, N. Efficacy of a natural mineral complex in North American adults with osteoarthritis of the knee: a randomized double-blind placebo-controlled study. Open Access Rheumatol.: Res. Rev. 6, 91-103 (2014).

7. WHO (World Health Organization). "Chronic Rheumatic Conditions." Chronic diseases and health promotion. http://www.who. int/chp/topics/rheumatic/en/ (2012).

8. Arthritis Alliance of Canada. The impact of arthritis in Canada: Today and over the next 30 years. http://www.arthritisalliance.ca/ images/PDF/eng/Initiatives/20111022_2200_impact_of_arthritis.pdf (2011).

9. NHPD 2015: Quality of natural health products guide: Health Canada. V3.1. https://www.canada.ca/en/health-canada/services/ drugs-health-products/natural-non-prescription/legislation-guidelines/guidance-documents/quality-guide.html (2015).

10. Intawongse, M. \& Dean, J. R. Use of the physiologically-based extraction test to assess the oral bioaccessibility of metals in vegetable plants grown in contaminated soil. Environ. Pollut. 152, 60-72 (2008).

11. He, M., Ke, C. H. \& Wang, W. X. Effects of cooking and subcellular distribution on the bioaccessibility of trace elements in two marine fish species. J. Agric. Food Chem. 58, 3517-3523 (2010).

12. Cheng, Y.-L., Presland, J. E., Anderson, M. B. \& George, W. J. Solubility and bioavailability of lead following oral ingestion of vitrified slagged aggregate. J. Hazard. Mater. 27, 137-147 (1991).

13. Mounicou, S., Szpunar, J., Andrey, D., Blake, C. \& Lobinski, R. Development of a sequential enzymolysis approach for the evaluation of the bioaccessibility of $\mathrm{Cd}$ and $\mathrm{Pb}$ from coca. Analyst 127, 1638-1641 (2002).

14. Laparra, J. M., Velez, D., Barbera, R., Montoro, R. \& Farre, R. Bioaccessiblity and transport by Caco-2 cells of organoarsenical species present in seafood. J. Agric. Food Chem. 55, 5892-5897 (2007).

15. Fu, J. \& Cui, Y. In vitro digestion/Caco-2 cell model to estimate cadmium and lead bioaccessiblity/bioavailabilty in two vegetables: the influence of cooking and additives. J. Food Chem. Toxicol. 59, 215-221 (2013).

16. Beyer, W. N. et al. Bioaccessibility tests accurately estimate bioavailability of lead to quail. Environ. Toxicol. Chem. 35(9), 2311-2319, https://doi.org/10.1002/etc.3399 (2016).

17. Denys, S., Tack, K., Caboche, J., \& Delalain, P. Assessing metals bioaccessibility to man in human health risk assessment of contaminated site. Conference DIFPOLMINE: Quel devenir pour les grands sites pollués par des métaux? What does the future hold for large metal-polluted sites, Montpellier, France. pp.NC (2006).

18. Wragg, J. et al. Inter-laboratory trial of a unified bioaccessibility testing procedure. Nottingham, UK, British Geological Survey. https://doi.org/10.1016/j.scitotenv.2011.05.019(2009).

19. Wragg, J. et al. An inter-laboratory trial of the unified BARGE bioaccessibility method for arsenic, cadmium and lead in soil. Sci. Total Environ. 409, 4016-4030 (2011).

20. Juhasz, A. L. et al. Comparison of in vivo and in vitro methodologies for the assessment of arsenic bioavailability in contaminated soils. Chemosphere. 69, 961-966 (2007).

21. Pan, W. et al. Bioaccessibility of heavy metals in vegetables and its association with the physicochemical characteristics. Environ. Sci. Pollut. Res. Int. 23(6), 5335-5341 (2016).

22. Rodriguez, R. R., Basta, N. T., Casteel, S. W. \& Pace, L. W. An in vitro gastrointestinal method to estimate bioavailable arsenic in contaminated soils and solid media. Environ. Sci. Technol. 33(4), 642-649 (1999).

23. Ruby, M. V., Davis, A., Schoof, R., Eberle, S. \& Sellstone, C. M. Estimation of lead and arsenic bioavailability using a physiologically based extraction test. Environ. Sci. Technol. 30(2), 422-430, https://doi.org/10.1021/es950057z (1996).

24. Pelfrene, A. et al. Bioaccessibility of trace elements as affected by soil parameters in smelter-contaminated agricultural soils: A statistical modeling approach. Environ. Pollut. 160, 130-138 (2012).

25. Maulvault, A. L. et al. Bioaccessibility of $\mathrm{Hg}$, Cd and As in cooked black scabbard fish and edible crab. J. Food Chem. Toxicol. 49, 2808-2815 (2011).

26. Neilson, A. P. \& Ferruzzi, M. G. Influence of formulation and processing on absorption and metabolism of flavan-3-ols from tea and cocoa. Ann. Rev. Food Sci. Technol. 2, 125-151 (2011).

27. Artursson, P., Palm, K. \& Luthman, K. Caco-2 monolayers in experimental and theoretical predictions of drug transport. Adv. Drug Deliv. Rev. 64, 280-289 (2012).

28. Garcia, M. N., Flowers, C. \& Cook, J. D. The Caco-2 cell culture system can be used as a model to study food iron availability. J. Nutri. 126, 251-258 (1996).

29. Glahn, R. P. et al. Decreased citrate improves iron availability from infant formula: application of an in vitro digestion/Caco-2 cell culture model. J. Nutri. 128, 257-264 (1998).

30. Glahn, R. P., Lee, O. A., Yeung, A., Goldman, M. I. \& Miller, D. D. Caco-2 cell ferritin formation predicts nonradiolabeled food iron availability in an in vitro digestion/Caco-2 cell culture model. J. Nutri. 128, 1555-1561 (1998).

31. Glahn, R. P. \& Van Campen, D. R. Iron uptake is enhanced in Caco-2 cell monolayers by cysteine and reduced cysteinyl glycine. J. Nutri. 127, 642-647 (1997).

32. Glahn, R. P., Wien, E. M., Van Campen, D. R. \& Miller, D. D. Caco-2 cell iron uptake from meat and casein digests parallels in vivo studies: Use of a novel in vitro method for rapid estimation of iron bioavailability. J. Nutri. 126(1), 332-9 (1996).

33. Siedlikowski, M. et al. Bioaccessibility and bioavailability of methylmercury from seafood commonly consumed in North America: In vitro and epidemiological studies. Environ. Res. 149, 266-273, https://doi.org/10.1016/j.envres.2016.02.013 (2016).

34. Morgan, J. N. Effects of Processing on Heavy Metal Content of Foods. Adv. Experi. Med. Biol. 459, 195-211 (1999).

35. Liu, B., Shiwei, A., Zhang, W., Huang, D. \& Zhang, Y. Assessment of the bioavailability, bioaccessibility and transfer of heavy metals in the soil-grain-human systems near a mining and smelting area in NW China. Sci. Total Environ. 609, 822-829 (2017).

36. FDA. Arsenic, lead and cadmium in food ingredients. https://www.fda.gov/Food/FoodborneIllnessContaminants/Metals/ ucm521427.htm\#arsenic_leadcadmium (2017).

37. Koch, I. et al. Bioaccessibility and excretion of arsenic in Niu Huang Jie Du Pian pills. Toxicol. Appl. Pharmacol. 222, 357-364 (2007).

38. Koch, I. et al. Bioaccessibility of lead and arsenic in traditional Indian medicines. Sci. Total Environ. 409, 4545-4552 (2011).

39. Calatayud, M. et al. Mercury and selenium in fish and shellfish: occurrence bioaccessibility and uptake by Caco-2 cells. J. Food Chem. Toxicol. 50, 2696-2702 (2012).

40. Tokalioglu, S., Clough, R., Foulkes, M. \& Worsfold, P. Bioaccessibility of Cr, Cu, Fe, Mg, Mn, Mo, Se and Zn from nutritional supplements by the unified BARGE method. Food chem. 150, 321-327 (2014).

41. USEPA. Guidance for evaluating the oral bioavailability of metals in soils for use in human health risk assessment. U.S. environmental protection agency, OSWER 9285, 7-80 (2007).

42. Denys, S. et al. In vivo validation of the unified BARGE method to assess the bioaccessibility of arsenic, antimony, cadmium, and lead in soils. Environ. Sci. Technol. 46, 6252-6260 (2012). 
43. Ringling, C. \& Rychlik, M. Simulation of food folate digestion and bioavailability of an oxidation product of 5-methyltetrahydrofolate. Nutrients. 9(9), 969, https://doi.org/10.3390/nu9090969 (2017).

44. Basta, N. T. \& Juhasz, A. Using In vivo bioavailability and/or in vitro gastrointestinal bioaccessibility testing to adjust human exposure to arsenic from soil ingestion. Rev. Mineral. Geochem. 9, 79 (2014).

45. US EPA, Methods for the Determination of Metals in Environmental Samples Supplement 1 (EPA/600/R-94/111), Rev 5.4, 1994, Method 200.8 Determination of Trace elements by Inductively Coupled Plasma - Mass Spectrometry.

46. USEPA method 1340. Validated test method 1340: In vitro bioaccessibility assay for lead in soil. https://www.epa.gov/sites/ production/files/2015-12/documents/1340.pdf (2015).

47. Chen, X., Elisia, I. \& Kitts, D. D. Defining conditions for the co-culture of Caco-2 and HT29-MTX cells using Taguchi design. J. Pharmacol. Toxicol. Methods. 61(3), 334-342 (2010).

\section{Acknowledgements}

This work was supported by a Mitacs-accelerated grant to D.D. Kitts, Xiumin Chen and Anika Singh. We thank SierraSil for the kind donation of mineral clays and contribution to NRC-BIAP. We thank EXOVA (Surrey, British Columbia, Canada, V3S-898) for assistance with heavy metal analysis and Ms. Kaiwen Mu for helping to prepare the digestion solutions and assisting in permeability study.

\section{Author contributions}

X.C. and D.D.K. designed the experiment, X.C. and D.D.K. acquired and analyzed data, X.C. and A.S. prepared tables and figures, A.S., D.D.K. and X.C. wrote the manuscript. All authors reviewed the manuscript.

\section{Competing interests}

The authors declare no competing interests.

\section{Additional information}

Correspondence and requests for materials should be addressed to D.D.K.

Reprints and permissions information is available at www.nature.com/reprints.

Publisher's note Springer Nature remains neutral with regard to jurisdictional claims in published maps and institutional affiliations.

(c) Open Access This article is licensed under a Creative Commons Attribution 4.0 International

License, which permits use, sharing, adaptation, distribution and reproduction in any medium or format, as long as you give appropriate credit to the original author(s) and the source, provide a link to the Creative Commons license, and indicate if changes were made. The images or other third party material in this article are included in the article's Creative Commons license, unless indicated otherwise in a credit line to the material. If material is not included in the article's Creative Commons license and your intended use is not permitted by statutory regulation or exceeds the permitted use, you will need to obtain permission directly from the copyright holder. To view a copy of this license, visit http://creativecommons.org/licenses/by/4.0/.

(C) The Author(s) 2020 